\title{
The Escherichia coli dsbA gene is partly transcribed from the promoter of a weakly expressed upstream gene
}

\author{
Pascal Belin and Paul Louis Boquet
}

Author for correspondence: Paul Louis Boquet. Tel: +331690872 90. Fax: +33169089071 .

CEA, Département d'Ingéniérie et d'Etudes des Protéines (DIEP), CE Saclay, 91191 Gif sur Yvette Cedex, France

\begin{abstract}
The dsbA gene of Escherichia coli encodes a periplasmic enzyme which catalyses disulfide bond formation. Analysis of its surrounding DNA region showed that it is preceded by an open reading frame, orfA, of 984 nucleotides. The intergenic region (19 nucleotides) carries no typical transcription termination signals. dsbA is transcribed from two promoters, the first (P1) lies in the distal part of orfA, and the second (P2) just upstream from orfA. Using a plasmid-borne dsbA::TnphoA fusion and an orfA:: $\Omega$ insertion, each promoter was shown to contribute equally to $d s b A$ transcription. The disruption of the single chromosomal copy of orfA by $\Omega$ more drastically reduced the amount of DsbA in the periplasmic space. Such a reduction of the DsbA pool, however, did not change the activities of the AppA, Agp and PhoA periplasmic phosphatases, which all require disulfide bond formation, even when the enzymes were produced from multicopy recombinant plasmids. Thus, in a wildtype strain, DsbA is far from being in limiting amounts for physiological requirements. The orfA gene product was identified as a weakly expressed $39 \mathrm{kDa}$ cytoplasmic protein, but it is not involved in the overall mechanism of disulfide bond formation.
\end{abstract}

Keywords: Escherichia coli, $d s b A$ gene, transcriptional organization, internal promoter, disulfide bond formation

\section{INTRODUCTION}

The folding of proteins in vivo takes place very rapidly because it is assisted by a variety of factors whose functions extend from preventing improper folding and aggregation to catalysing rate-limiting steps such as proline cis/trans isomerization and disulfide bond formation in secreted proteins. These factors are widely distributed among the different organisms, and most of the cellular compartments have their own representative (Gething \& Sambrook, 1992). Until recently, little was known about the folding of bacterial secreted proteins, although a disulfide isomerase activity had been detected in the periplasmic space of Escherichia coli (Barth et al., 1988). A gene, $d s b A$, encoding a periplasmic protein involved in this process, has been identified at $87 \mathrm{~min}$ on the E. coli linkage map by several groups (Bardwell et al.,

\footnotetext{
Abbreviations: $A P$, alkaline phosphatase; SD, Shine-Dalgarno; Amp, ampicillin; Cm, chloramphenicol; Spc, spectinomycin; Str, streptomycin; Tet, tetracycline.

The EMBL accession number for the sequence data reported in this paper is X80762.
}

1991; Kamitani et al., 1992; Belin et al., 1994) and shown to exist also in other micro-organisms (Peek \& Taylor, 1992; Yu et al., 1992; Tomb, 1992). The DsbA protein contains a Cys-X-X-Cys motif common to several thioldisulfide oxido-reductases and is able to catalyse the formation of disulfide bridges in vitro (Akiyama et al., 1992). The oxidized form has an intrachain disulfide bridge of high instability and transfers this oxidized state to cysteine residues of substrate proteins very efficiently, the DsbA protein being reduced in the process (Zapun $e t$ al., 1993). The amount of DsbA in the periplasmic space has been estimated at around 850 molecules per cell (Akiyama et al., 1992). However, periplasmic proteins containing disulfide bonds such as AppA and Agp (acid phosphatases) or PhoA (alkaline phosphatase) can be over-produced from recombinant plasmids in their mature state, to levels of $60-80 \%$ of total periplasmic proteins. This implies a very efficient reoxidation of reduced DsbA which takes place even under anaerobic conditions (Belin et al., 1994). Another gene ( $d s b B$ or $d s b X)$, whose inactivation leads to a phenotype very similar to that of $d s b A$ mutants, has been identified at 26 min on the E. coli linkage map (Bardwell et al., 1993; 
Table 1. Characteristics of strains and plasmids

\begin{tabular}{|c|c|c|}
\hline $\begin{array}{l}\text { Strain or } \\
\text { plasmid }\end{array}$ & Description of the genotype & Source \\
\hline \multicolumn{3}{|l|}{ E. coli } \\
\hline $\mathrm{CC} 118$ & $\begin{array}{l}\mathrm{F}^{-} \Delta(\text { ara leu }) 7697 \Delta l a c X 74 \Delta p h o A 20 \text { galE galK thi rpsE rpoB } \\
\operatorname{argE(Am)rec~} A 1\end{array}$ & $\begin{array}{l}\text { C. Manoil (University of Washington, } \\
\text { Seattle) }\end{array}$ \\
\hline CSR 603 & $\begin{array}{l}\mathrm{F}^{-} \text {argE3 aro-14 galK2 leuB manI phr-1 pro } A 2 \text { rec } A 1 \text { rpsL31 supE44 } \\
\text { thi thr-1 wor } A 6 \text { xyl-5 }\end{array}$ & E. Dassa (Pasteur Institute, Paris) \\
\hline $\mathrm{K} 10$ & $\mathrm{HfrC}$ rel $A$ ton $A 22$ pit-10 & $\begin{array}{l}\text { B. Bachmann (Yale University, New } \\
\text { Haven) }\end{array}$ \\
\hline SBS2227 & Same as $\mathrm{K} 10$, but $\operatorname{orf} A:: \Omega$ & This study \\
\hline SBS2171 & $\begin{array}{l}\mathrm{HfrC} \text { rel } A \text { pit-10 ton } A 22 \text { thi pol } A 12(\mathrm{ts}) \operatorname{Tn} 10-64(\operatorname{Tn} 1090 \% \\
\text { cotransducible with pol } A)\end{array}$ & This study \\
\hline SBS2280 & Same as $\mathrm{K} 10$, but $d s b B:: \operatorname{Tn} 10$ & This laboratory \\
\hline \multicolumn{3}{|l|}{ Plasmids } \\
\hline pHSG575 & $\mathrm{Cm}^{\mathrm{r}}$ & D. Touati (University Paris VII) \\
\hline $\mathrm{pHP} 45 \Omega$ & $A m p^{r} S_{t r}{ }^{r} S p c^{r}$ & J. P. Bohin (University Paris Sud) \\
\hline pBR322 & $A m p^{r} \mathrm{Tet}^{r}$ & $\begin{array}{l}\text { J. Beckwith (Harvard Medical School, } \\
\text { Boston) }\end{array}$ \\
\hline pPB1132 & $\mathrm{Amp}^{\mathrm{r}} a p p B A$ & This laboratory \\
\hline pEP1376 & $A m p^{r} a g p$ & This laboratory \\
\hline pPB2142 & $\begin{array}{l}\mathrm{Cm}^{\mathrm{r}} d s b A \text { (HindIII-HindIII insert into the HindIII site of } \\
\text { pHSG575) }\end{array}$ & See Fig. 1 \\
\hline pPB2144 & $\begin{array}{l}\mathrm{Cm}^{\mathrm{r}} \text { mob orf } A\left(E c o \mathrm{RI}-P_{s t} \mathrm{I} \text { insert into the EcoRI-PstI sites of }\right. \\
\text { pHSG575) }\end{array}$ & See Fig. 1 \\
\hline pPB2181 & $\mathrm{Amp}^{\mathrm{r}} d s b A 71(\mathrm{Oc})$ & This laboratory \\
\hline pРB2196 & $\begin{array}{l}\text { Amp }{ }^{\mathrm{r}} \text { orf } A d s b A\left(K p n \mathrm{I}^{*}-C l a \mathrm{I} \text { insert into the HindIII*-ClaI sites of }\right. \\
\text { pBR322) }\end{array}$ & See Fig. 1 \\
\hline pPB2212 & $\begin{array}{l}\mathrm{Amp}^{\mathrm{r}} \mathrm{Tet}^{\mathrm{s}} d s b A(\text { HindIII}-S s p \mathrm{I} \text { insert into the HindIII-NruI sites of } \\
\text { pBR322) }\end{array}$ & See Fig. 1 \\
\hline pPB2216 & $\begin{array}{l}\text { Amp }{ }^{\mathrm{r}} \text { orf } A d s b A\left(K p n \mathrm{I}^{*}-S_{s p \mathrm{I}} \text { insert into the HindIII*-NruI sites of }\right. \\
\text { pBR322) }\end{array}$ & See Fig. 1 \\
\hline pPB2217 & $\begin{array}{l}\mathrm{Amp}^{\mathrm{r}} \operatorname{Str}^{\mathrm{r}} \mathrm{Spc}^{\mathrm{r}} \text { orf } A:: \Omega d s b A(\text { BamHI } \Omega \text { fragment inserted into the } \\
\text { BamHI site of orf } A \text { on } \mathrm{pPB} 2216)\end{array}$ & This study \\
\hline pPB2234 & $\begin{array}{l}\text { Amp }{ }^{\mathrm{r}} \text { orf } A d s b A\left(S m a \mathrm{I}-S_{s p \mathrm{I}} \text { insert into the EcoRI*-NruI sites of }\right. \\
\mathrm{pBR} 322)\end{array}$ & See Fig. 1 \\
\hline pPB2317 & $A_{m p}{ }^{r} d s b A:: \operatorname{Tn} p h o A$ & This laboratory \\
\hline pPB2352 & $\begin{array}{l}\text { Amp }{ }^{\mathrm{r}} \operatorname{orf} A d s b A\left(N s i I^{*}-S_{s p} \mathrm{I} \text { fragment into the EcoRI*-NruI sites }\right. \\
\text { of } \mathrm{pBR} 322)\end{array}$ & This study \\
\hline pPB2353 & $\begin{array}{l}\text { Amp }{ }^{r} \text { orf } A d s b A:: \operatorname{Tn} p b o A \text { (HpaI fragment from } \mathrm{pPB} 2317 \text { into the } \\
\text { HpaI sites of } \mathrm{PPB} 2352)\end{array}$ & See Fig. 5 \\
\hline pPB2354 & $\begin{array}{l}\text { Amp }{ }^{\mathrm{r}} \operatorname{orf} A d s b A:: \operatorname{Tn} p h o A(\mathrm{a} 4.8 \mathrm{~kb} \Delta X b o \mathrm{I} \text { deletion on plasmid } \\
\text { pPB2353) }\end{array}$ & See Fig. 5 \\
\hline pPB2355 & $\begin{array}{l}\text { Amp }{ }^{\mathrm{r}} \operatorname{Str}^{\mathrm{r}} \operatorname{Spc}^{\mathrm{r}} \text { orf } A \text { dsba } A:: \operatorname{Tn} p h o A(S m a \mathrm{I} \Omega \text { fragment inserted } \\
\left.\text { into the } X b \mathrm{I}^{*} \text { site of } \mathrm{pPB} 2354\right)\end{array}$ & See Fig. 5 \\
\hline pPB2358 & $\begin{array}{l}\mathrm{Amp}^{\mathrm{r}} \operatorname{Str}^{\mathrm{r}} \mathrm{Spc}^{\mathrm{r}} \text { orf } A:: \Omega d s b A:: \operatorname{Tn} p h o A(B a m \mathrm{HI} \Omega \text { fragment } \\
\text { inserted into the BamHI site of orf } A \text { on } \mathrm{pPB} 2354)\end{array}$ & See Fig. 5 \\
\hline pPB2359 & $\begin{array}{l}A m p^{r} \operatorname{Str}^{r} \operatorname{Spc}^{\mathrm{r}} \text { orf } A d s b A:: \operatorname{Tn} p b o A(S m a \mathrm{I} \Omega \text { fragment inserted into } \\
\text { the } S m a \mathrm{I} \text { site of } \mathrm{pPB} 2354)\end{array}$ & See Fig. 5 \\
\hline pPB2360 & $\begin{array}{l}\text { Amp }{ }^{\mathrm{r}} \Delta(\mathrm{P} 2) o r f A d s b A:: \text { Tnpho } A \text { (a } 113 \text { nucleotide } S m a \mathrm{I}-E c o \mathrm{RV} \\
\text { deletion on } \mathrm{pPB} 2354)\end{array}$ & This study \\
\hline pPB2366 & $\mathrm{Amp}^{\mathrm{r}} d s b A(\mathrm{a} 0.9 \mathrm{~kb} \Delta$ HindIII deletion on pPB2234) & See Fig. 1 \\
\hline pPB2394 & $\begin{array}{l}\mathrm{Amp}^{\mathrm{r}} \Delta(\mathrm{P} 2-\operatorname{orf} A) d s b . A:: \operatorname{Tn} p h o A(\text { a } 107 \text { nucleotide } \\
\text { EcoRV-BamHI* deletion on } \mathrm{pPB} 2354)\end{array}$ & This study \\
\hline pPB2395 & $\begin{array}{l}\text { Amp }{ }^{\mathrm{r}} \text { orf } A^{\prime} d s b A:: \operatorname{Tn} p h o A \text { (BamHI digestion, fill-in and ligation on } \\
\text { pPB2354) }\end{array}$ & This study \\
\hline
\end{tabular}

* Sites that have been filled with T4 DNA polymerase. 


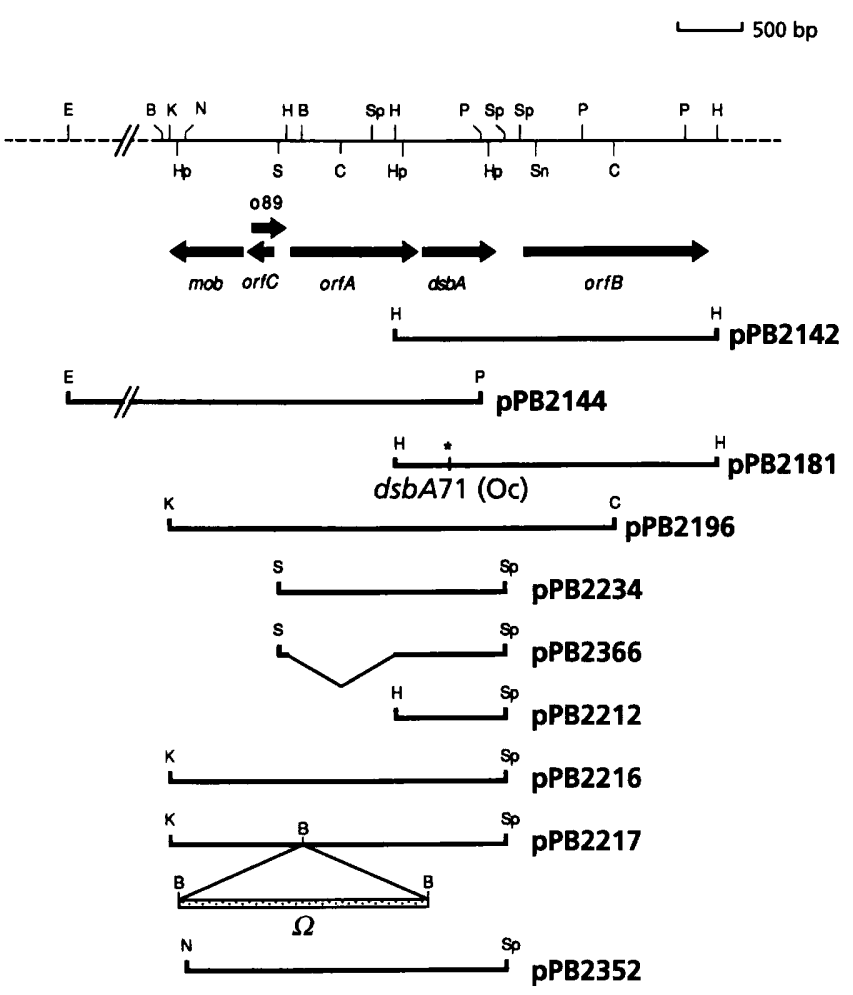

Fig. 1. Restriction map of the $d s b A$ region, deduced from the DNA sequence. Dashed lines correspond to unsequenced DNA. The solid arrows indicate the positions and orientations of the open reading frames; 089 has been described by Plunkett $e t$ al. (1993). Plasmid designations and DNA regions cloned are indicated. The $\Omega$ fragment is shown as a stippled box. Restriction sites: B, BamHI; C, Clal; E, EcoRl; H, Hindlll; Hp, Hpal; K, Kpnl; N, Nsil; P, Pstl; S, Smal; Sn, SnaBI; Sp, Sspl.

Dailey \& Berg, 1993; Belin \& Boquet, 1993; Missiakas et al., 1993). Nucleotide sequence analysis showed that the encoded protein has the characteristics of an integral membrane protein (Bardwell et al., 1993; Missiakas et al., 1993). Inactivation of $d s b B$ is rescued by the addition to the culture medium of oxidized glutathione (Bardwell et al., 1993; Belin \& Boquet, 1993) or cystine (Bardwell et al., 1993; Dailey \& Berg, 1993), strongly suggesting that the DsbB protein is involved in DsbA reoxidation.

At present there is no information available about possible regulation of DsbA production as a function of the need for this factor or in response to physiological changes. Recently, Plunkett et al. (1993) published the E. coli genome nucleotide sequence from $87.2 \mathrm{~min}$ to $89 \cdot 2 \mathrm{~min}$. The $d s b A$ gene, included in this region, was found to be preceded by an open reading frame, referred to as 0328 . No sequences resembling putative terminators of transcription can be distinguished upstream of $d s b A$ (Kamitani et al., 1992; Plunkett $e$ al., 1993). Furthermore, Plunkett et al. (1993) identified, by computer analysis, two putative promoters upstream of 0328 which could transcribe 0328 and $d s b A$ simultaneously. The aim of this study was to analyse $d s b A$ transcription and expression. We have identified the 0328 gene product, and analysed the consequences of its disruption on growth, DsbA production and disulfide bond formation.

\section{METHODS}

Strains, growth conditions and genetic techniques. All the strains used in this study are derivatives of Escherichia coli K12 and are described in Table 1. Transductions were made with phage $\mathrm{P} 1_{\text {vir }}$ according to Miller (1972). Cells were grown in TYE medium (bacto tryptone, $10 \mathrm{~g} \mathrm{l}^{-1}$; yeast extract, $5 \mathrm{gl}^{-1}$; and $\mathrm{NaCl}, 8 \mathrm{~g} \mathrm{l}^{-1}, \mathrm{pH} 7 \cdot 5$ ) as a rich medium. Ampicillin (Amp) was added to a final concentration of $200 \mu \mathrm{g} \mathrm{ml}^{-1}$ and chloramphenicol $(\mathrm{Cm})$ at $10 \mu \mathrm{g} \mathrm{ml}^{-1}$, unless otherwise stated. Streptomycin (Str), spectinomycin (Spc) and tetracycline (Tet) were added as indicated in the text. The induction of the $\mathrm{P}_{t a c}$ promoter was obtained with IPTG $(2 \mathrm{mM})$.

Plasmids and DNA manipulations. The plasmids used in this study are listed in Table 1. Plasmid DNA manipulations were performed according to Sambrook et al. (1989). The $\Omega$ interposon was isolated from plasmid $\mathrm{pHP} 45 \Omega$ constructed by Prentki \& Krisch (1984).

Genomic DNA extraction and analysis by PCR. Genomic DNA was isolated according to Silhavy et al. (1984). The analysis of genomic DNA by PCR was performed using oligonucleotide 5' GATTCAATAAAGTCTGACCGT 3' which is complementary to nucleotide position 272-292 of orf $A$ (o328), and oligonucleotide 5' CGCGGCGTAATTAAAGAGTAAAA 3', which corresponds to a nucleotide sequence lying just before the HindIII site 70 nucleotides upstream from the initiation codon of $\operatorname{orf} A$. PCR amplification was carried out in $100 \mu$ l volumes containing $1 \mu \mathrm{g}$ DNA and $10 \mathrm{ng}$ of each oligonucleotide in standard buffer supplemented with $10 \%$ (v/v) DMSO (Khalil et al., 1992). Reactions were heated to $95^{\circ} \mathrm{C}$ for $5 \mathrm{~min}$, and $2.5 \mathrm{U}$ Taq DNA polymerase was added to each reaction. Thirty cycles were performed as follows: melting at $92{ }^{\circ} \mathrm{C}$ for $1 \mathrm{~min}$, annealing at $50^{\circ} \mathrm{C}$ for $1 \mathrm{~min}$ and extension at $72{ }^{\circ} \mathrm{C}$ for $1 \mathrm{~min}$ (extension $5 \mathrm{~s}$ at each cycle). After a $10 \mathrm{~min}$ extension at $72^{\circ} \mathrm{C}$, $10 \mu \mathrm{l}$ of each reaction was analysed on $1 \%(\mathrm{w} / \mathrm{v})$ agarose gel (Sambrook et al., 1989).

DNA sequencing and sequence analysis. Nucleotide sequence determinations were made on both strands of plasmid DNA using the Pharmacia T7 sequencing kit. Denaturation of plasmid DNA and sequence reactions were performed according to the instructions of the manufacturer. The sequence data were analysed with the DNA Strider 1.2 program (Marck, 1988). Homologies were searched for in the NBRF databases (release number 38) by using the BISANCE facilities (Dessen et al., 1990).

Maxicell analysis. Plasmids pBR322, pPB2196, pPB2234, pPB2181 and pPB2366 were introduced into strain CSR603 by transformation. Maxicells were prepared from transformants according to Sancar et al. (1979), and radioactive proteins were analysed by SDS-PAGE (Laemmli, 1970) and autoradiography.

RNA preparation and primer extension. RNA was isolated from strain CC118 carrying plasmid pPB2196 according to Aïba et al. (1981) with some modifications. The bacterial pellet from $2 \mathrm{ml}$ of culture was resuspended in $200 \mu \mathrm{l} 0.02 \mathrm{M}$ sodium acetate (pH 5.5), $0.5 \%$ SDS, $0.001 \mathrm{M}$ EDTA and $0.1 \%$ diethyl pyrocarbonate, then $400 \mu \mathrm{l}$ of hot phenol equilibrated with $0.02 \mathrm{M}$ sodium acetate $(\mathrm{pH} 5.5)$ was added and the bacterial suspension was incubated for $5 \mathrm{~min}$ at $60^{\circ} \mathrm{C}$ after briefly vortexing. After centrifugation, the aqueous layer was decanted and re-extracted twice with hot phenol. RNAs were precipitated with $0 \cdot 1$ vols $\mathrm{NaCl}(5 \mathrm{M})$ and 3 vols ethanol, and the solution was left for $1 \mathrm{~h}$ at $-70^{\circ} \mathrm{C}$. After centrifugation, the RNA pellet 
cgatatcgcctctttattgtgggattgaccctgctaacgtgtctgtctcaagagtaaggagcatcactatgaaatgtaa

acgtctgaatgaagttattgaact cctccagccagcctggcaaaagagccagaccttaacctgctgcaattttgcaga

aactggcgaaagagtcaggttttgacggcgaactggcggatttgacggatgacattctgatctatcacctgaaaatgcgt

gattccgcgaaagatgcggtgatcccgggtttgcagaaagattatgaagaagacttcaaaacggcgctgttacgcgctcg $-10$

cggcgtaattaaagagtaaaagcttgtaagcggcgccaccaaaatcatcgtgaaatgatatccttcgtcattcgtaatgt SD

tttccggatgatggg ATG AAT AAC AGC GCT TT' ACT TTC CAG ACA CTA CAC CCG GAT ACC ATC

$$
\begin{array}{llllllllllllllllll}
M & N & N & S & A & F & T & F & Q & T & L & H & P & D & T & I
\end{array}
$$

ATG GAC GCT CTG TTT GAG CAT GGG ATC CGG GTG GAT TCC GGT CTT ACC CCG CTT AAC AGC

$\begin{array}{llllllllllllllllllll}M & \text { D } & \text { A } & \text { L } & \text { F } & \text { E } & \text { H } & \text { G } & \text { I } & \text { R } & \text { V } & \text { D } & \text { S } & \text { G } & \text { L } & \text { T } & \text { P } & \text { L } & \text { N } & S\end{array}$

TAT GAA AAC CGT GTC TAT CAA TTT CAG GAC GAA GAT CGT CGA CGT TTT GTC GTC AAA TTT

$\begin{array}{lllllllllllllllllllll}\mathrm{Y} & \mathrm{E} & \mathrm{N} & \mathrm{R} & \mathrm{V} & \mathrm{Y} & \mathrm{Q} & \mathrm{F} & \mathrm{Q} & \mathrm{D} & \mathrm{E} & \mathrm{D} & \mathbf{R} & \mathrm{R} & \mathrm{R} & \mathrm{F} & \mathrm{V} & \mathrm{V} & \mathrm{K} & \mathrm{F}\end{array}$

TAT CGC CCT GAA CGT TGG ACA GCC GAT CAA ATC CTC GAA GAA CAT CAA TTT GCG TTG CAG

$\begin{array}{lllllllllllllllllllll}\mathrm{Y} & \mathrm{R} & \mathrm{P} & \mathrm{E} & \mathrm{R} & \mathrm{W} & \mathrm{T} & \mathrm{A} & \mathrm{D} & \mathrm{Q} & \mathrm{I} & \mathrm{L} & \mathrm{E} & \mathrm{E} & \mathrm{H} & \mathrm{Q} & \mathrm{F} & \mathrm{A} & \mathrm{L} & \mathbf{Q}\end{array}$

CTG GTA AAT GAT GAA GTT CCG GTC GCA GCA CCT GTG GCC TTT AAC GGT CAG ACT TTA TTG

$\begin{array}{lllllllllllllllllllll}\mathrm{L} & \mathrm{V} & \mathrm{N} & \mathrm{D} & \mathrm{E} & \mathrm{V} & \mathrm{P} & \mathrm{V} & \mathrm{A} & \mathrm{A} & \mathrm{P} & \mathrm{V} & \mathrm{A} & \mathbf{F} & \mathrm{N} & \mathrm{G} & \mathrm{Q} & \mathrm{T} & \mathrm{L} & \mathrm{L}\end{array}$

AAT CAT CAG GGA TTT TAT TTC GCT GTT TTT CCA AGC GTC GGT GGT CGC CAG TTC GAA GCT

1438

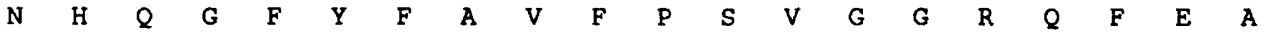

GAT AAT ATC GAT CAG ATG GAA GCG GTT GGG CGT TAT TTA GGG CGT ATG CAC CAG ACG GGG

1498

$\begin{array}{llllllllllllllllllll}\mathrm{D} & \mathrm{N} & \mathrm{I} & \mathrm{D} & \mathbf{Q} & \mathbf{M} & \mathrm{E} & \mathrm{A} & \mathrm{V} & \mathrm{G} & \mathrm{R} & \mathrm{Y} & \mathrm{L} & \mathrm{G} & \mathbf{R} & \mathbf{M} & \mathrm{H} & \mathbf{Q} & \mathrm{T} & \mathbf{G}\end{array}$

CGC AAA CAG CTT TTT ATC CAT CGC CCG ACC ATC GGT TTG AAC GAA TAT CTC ATT GAG CCA

1558

$\begin{array}{llllllllllllllllllll}R & K & Q & \text { L } & \text { F } & \text { I } & \text { H } & \text { R } & \text { P } & \text { T } & \text { I } & \text { G } & \text { L } & \text { N } & \text { E } & \text { Y } & \text { L } & \text { I } & \text { E } & \text { P }\end{array}$

CGC AAG CTG TTT GAG GAC GCT ACA CTG ATA CCT TCC GGG TTG AAA GCG GCA TTC CTG AAA

$\begin{array}{llllllllllllllllllll}\mathrm{R} & \mathrm{K} & \mathrm{L} & \mathrm{F} & \mathrm{E} & \mathrm{D} & \mathrm{A} & \mathrm{T} & \mathrm{L} & \mathrm{I} & \mathrm{P} & \mathrm{S} & \mathrm{G} & \mathrm{L} & \mathrm{K} & \mathrm{A} & \mathrm{A} & \mathrm{F} & \mathrm{L} & \mathrm{K}\end{array}$

GCG ACA GAT GAG CTG ATT GCC GCC GTT ACA GCA CAC TGG CGG GAA GAT TTC ACC GTT CTG

$\begin{array}{llllllllllllllllllll}\text { A } & \mathrm{T} & \mathrm{D} & \mathrm{E} & \mathrm{L} & \mathrm{I} & \mathrm{A} & \mathrm{A} & \mathrm{V} & \mathrm{T} & \mathrm{A} & \mathrm{H} & \mathrm{W} & \mathrm{R} & \mathrm{E} & \mathrm{D} & \mathrm{F} & \mathrm{T} & \mathrm{V} & \mathrm{L}\end{array}$

1738

CGG CTA CAT GGA GAC TGC CAC GCC GGG AAT ATT CTC TGG CGC GAT GGT CCA ATG TTT GTT

$\begin{array}{llllllllllllllllllll}R & \text { L } & \text { H } & \text { G } & \text { D } & \text { C } & \text { H } & \text { A } & \text { G } & \text { N } & \text { I } & \text { L } & \text { W } & \text { R } & \text { D } & \text { G } & \text { P } & \text { M } & \text { F } & \text { V }\end{array}$

1798

GAT CTG GAT GAT GCA CGT AAT GGT CCA GCC GTT CAG GAT TTG TGG ATG TTG CTC AAT GGC

$\begin{array}{lllllllllllllllllllll}D & \text { L } & \text { D } & \text { D } & \text { A } & \text { R } & \text { N } & \text { G } & \text { P } & \text { A } & \text { V } & \text { Q } & \text { D } & \text { L } & \text { W } & \text { M } & \text { L } & \text { L } & \text { N } & \text { G }\end{array}$

1858

GAT AAA GCC GAG CAG CGG ATG CAA CTG GAA ACT ATT ATT GAA GCT TAT GAA GAA TTT AGC

GAG TTC GAC ACC GCT GAA ATC GGA CTG ATT GAA CCT TTA CGC GCC ATG CGT TTG GTT TAT

TAT CTT GCC TGG CTA ATG CGG CGT TGG GCT GAT CCC GCG TTC CCG AAA AAT TTC CCG TGC

Fig. 2. For legend see facing page. 
was rinsed with $70 \%(\mathrm{v} / \mathrm{v})$ ethanol, vacuum-dried and dissolved in distilled water. RNA concentration was determined by absorbance at $260 \mathrm{~nm}$ and the RNA was stored at $-20^{\circ} \mathrm{C}$.

For reverse transcriptase analysis, the oligonucleotides 5' CT'TCAAACTGATAGCAGTGCGGGC 3', which is complementary to position 146-169 of the $d s b A$ gene, and 5' GGATCCCATGCTCAAACAGAGCGTCCATGAT 3', which is complementary to position 46-76 of $\operatorname{orf} A$, were used. The oligomers were $5^{\prime}$ end-labelled by using polynucleotide kinase and $\left[\gamma_{-}{ }^{32} \mathrm{P}\right]$ ATP. A molar excess of oligonucleotides was annealed with a different amount of RNA according to Sambrook et al. (1989). Primer extension analysis was performed according to Sambrook et al. (1989). The products of the primer extensions were analysed by electrophoresis on an $8 \%(\mathrm{w} / \mathrm{v})$ polyacrylamide-urea gel and autoradiography.

Analysis of proteins. The enzymic specific activities of $\mathrm{pH} 2.5$ acid phosphatase, glucose-1-phosphatase and alkaline phosphatase were measured and expressed as reported previously (Dassa et al., 1982; Pradel \& Boquet, 1988; Belin et al., 1994).

Periplasmic extracts were prepared by an osmotic shock procedure (Neu \& Heppel, 1965) and were submitted to analysis by SDS-PAGE according to Laemmli (1970) and silver-stained (Blum et al., 1987).

\section{RESULTS}

\section{Nucleotide sequence analysis and genetic organization of the $d s b A$ region}

The cloning of the $d s b A$ gene with phagemid MudII5117 has been reported previously and the recombinant clones carried large fragments lying upstream and downstream from $d s b A$ (Belin et al., 1994). The $d s b A$ upstream region was subcloned by inserting a $5.6 \mathrm{~kb}$ EcoRI-Pst fragment between the EcoRI and PstI sites of the vector pHSG575 (Takeshita et al., 1987), yielding plasmid pPB2144 (Fig. 1). The $d s b A$ downstream region was also subcloned on pHSG575 yielding plasmid pPB2142, already described (Fig. 1; Belin et al., 1994).

Nucleotide sequence analysis was performed on both DNA strands and extended from a BamHI site lying $2.1 \mathrm{~kb}$ upstream of the $d s b A$ ATG initiation codon to a HindIII site located $2.3 \mathrm{~kb}$ downstream from the same triplet (Fig. 1). This sequence corresponds to the fragment located between positions 3664 and 3660 of Kohara's map (Kohara et al., 1987).

The $d s b A$ gene was found to be followed by a 1428 nucleotide open reading frame named orf $B$ and encoding a putative polypeptide of 476 amino acid residues. The difference in length with 0490 described by Plunkett $e t$ al. (1993) results from the choice of the start codon. Here we ascribed ATG as the initiation codon for $\operatorname{orf} B$, rather than the GTG triplet found 42 nucleotides upstream. $d s b A$ and orf $B$ were found to be separated by sequences similar to a typical $\rho$-independent terminator of transcription, indicating that they very likely belong to different transcrip- tional units. The orf $B$ open reading frame is followed by a structure which could form an RNA hairpin, and could correspond to a terminator of transcription.

The sequence immediately upstream from $d s b A$ contains another open reading frame, $\operatorname{orf} A$ (Fig. 2). It is 984 nucleotides long and terminates only 19 nucleotides upstream from the ATG initiation codon of $d s b A$. This sequence potentially encodes a polypeptide of 328 amino acid residues with a calculated molecular mass of $38096 \mathrm{Da}$ and with a codon adaptation index (CAI) of $0 \cdot 270$ (Sharp \& $\mathrm{Li}, 1987$ ). The nucleotide sequence of $\operatorname{orf} A$ was found to be identical to 0328 described by Plunkett et al. (1993). No significant homology with any of the proteins in the NBRF database were found. As noted by Plunkett et al. (1993), no typical terminator of transcription can be found between $\operatorname{orf} A$ and $d s b A$.

The mob gene lies 416 nucleotides upstream from the $\operatorname{orf} A$ initiation codon and is transcribed in the opposite direction (Plunkett $e t$ al., 1993). The region between the mob gene and $\operatorname{orf} A$ contains a short open reading frame named 089 by Plunkett and coworkers. It is also possible to see a small open reading frame, $\operatorname{orf} C$, on the other DNA strand of this intergenic region, preceding the mob gene and transcribed in the same direction (Fig. 1).

We found some differences between the present nucleotide sequence and that described by Plunkett et al. (1993). Firstly, their sequence reads 4015 TGATAATCCT 4024, while our sequence reads TGATATCT: the supernumerary $\mathrm{A}$ (underlined) would eliminate the EcoRV site (bold type) found 33 nucleotides before $\operatorname{orf} A$. We found that this restriction site actually exists, as also described by Kohara et al. (1987). Secondly, three differences were found in the putative $d s b A$ transcription terminator. However, none of the other authors who have sequenced this region (Bardwell et al., 1991; Kamitani et al., 1992) obtained exactly the same nucleotide sequence. Thirdly, individual nucleotide substitutions were found within $\operatorname{orf} B(\mathrm{o} 490)$, which did not change the reading frame.

\section{Identification of the orfA gene product}

To determine whether $\operatorname{orf} A$ was actually expressed as a gene, maxicell analysis was performed with strain CSR603 harbouring either plasmid $\mathrm{pPB} 2234$, which carries orf $A$ and $d s b A$ on a $S m a I-S s p I$ fragment inserted between the EcoRI and NruI sites of pBR322, or plasmid pPB2196, which contains a larger $\operatorname{orf} A$ upstream DNA region (Fig. 1). In addition to the DsbA protein (apparent molecular mass $24 \mathrm{kDa}$, Bardwell et al., 1991) and $\beta$-lactamase (two bands around $30 \mathrm{kDa}$, Sancar et al., 1979), the plasmids were found to encode a polypeptide with an apparent molecular mass of $39 \mathrm{kDa}$. A partial deletion of $\operatorname{orf} A$ was constructed on plasmid pPB2234 between both HindIII sites, resulting in plasmid pPB2366. This plasmid did not

Fig. 2. Nucleotide sequence of the orfA gene and its flanking regions. The orf $A$ gene and the beginning of the $d s b A$ gene are translated into protein. SD indicates the putative Shine-Dalgarno sequences. The origins of transcription are indicated by 0 . The deduced -10 and -35 regions are overlined. The Smal, EcoRV and BamHI restriction sites are indicated. 


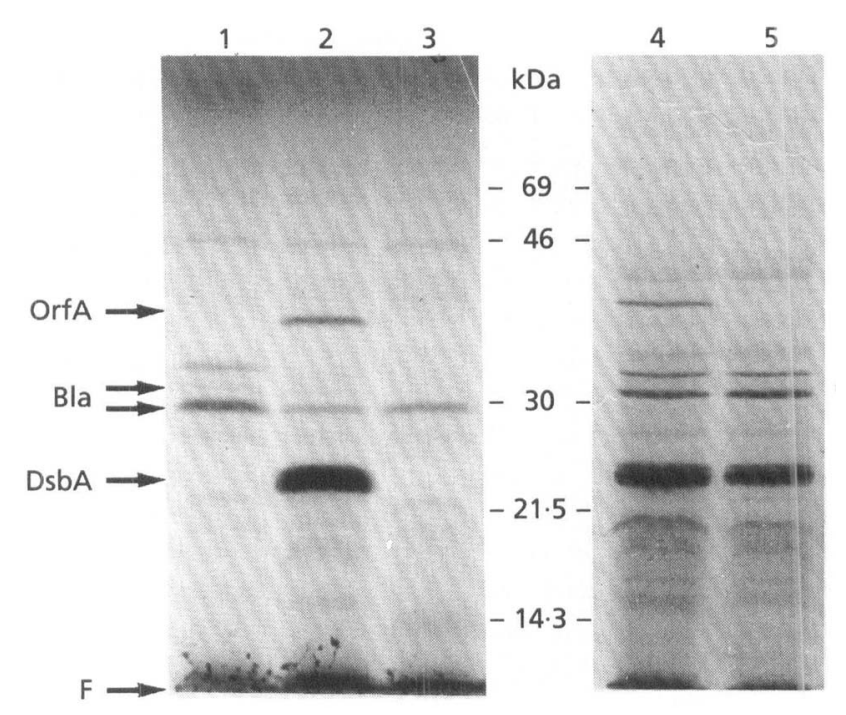

Fig. 3. Identification of the product encoded by the orfA and dsbA genes. Autoradiogram of an SDS-polyacrylamide gel of lysates prepared from ${ }^{35} \mathrm{~S}$-labelled maxicells obtained from strain CSR603 harbouring plasmid pBR322 (lane 1), pPB2196 (orf $A^{+} d s b A^{+}$, lane 2), pPB2181 as control [dsbA71 (Oc), lane 3], pPB2234 (orfA ${ }^{+}, d s b A^{+}$, lane 4) or pPB2366 ( $\Delta$ orfA $d s b A^{+}$, lane 5). Plasmid structures are indicated in Fig. 1 (note that plasmid pPB2181 does not carry the orfA region).

produce the $39 \mathrm{kDa}$ polypeptide in maxicells (Fig. 3). Therefore, $\operatorname{orf} A$ actually encodes this polypeptide. The absence of a typical signal peptide and of hydrophobic regions similar to membrane-spanning domains in the $\operatorname{orf} A$ amino acid sequence indicates that it is probably a cytoplasmic protein. Furthermore, we have obtained active $\operatorname{Tn} l a c Z$ fusions all along the $\operatorname{orf} A$ gene on plasmid pPB2234. After cellular fractionation of bacteria carrying such a fusion plasmid, the $\beta$-galactosidase activity was localized to the cytoplasmic fraction, as opposed to being membrane-associated (data not shown).

The products of the 089 or orfC genes carried by plasmid pPB2196 were not observed in our maxicell analyses.

\section{Determination of the origins of transcription of $d s b A$ and orfA}

The interval between $\operatorname{orf} A$ and $d s b A$ appears too small to contain a promoter region, and as previously noted by Kamitani et al. (1992), no typical promoter sequence can be identified unambiguously for $d s b A$. However, a $d s b A$ mutation was complemented by plasmid pPB2212, which carries the $d s b A$ gene on a HindIII- $S_{s p \text { I fragment inserted }}$ between the HindIII and NruI sites of pBR322 (Fig. 1). Inserting a $2 \mathrm{~kb} \Omega$ interposon which contains a $\operatorname{Str}^{\mathrm{r}}$ and $\mathrm{Spc}^{\mathrm{r}}$ gene flanked by transcription and translation termination signals, and multiple cloning sites (Prentki \& Krisch, 1984) into the HindIII site of pPB2212 did not change its complementing activity as well as the amount of DsbA produced in the periplasmic space (data not shown). This rules out the possibility that, on pPB2212, $d s b A$ could be transcribed from a pBR322 endogenous
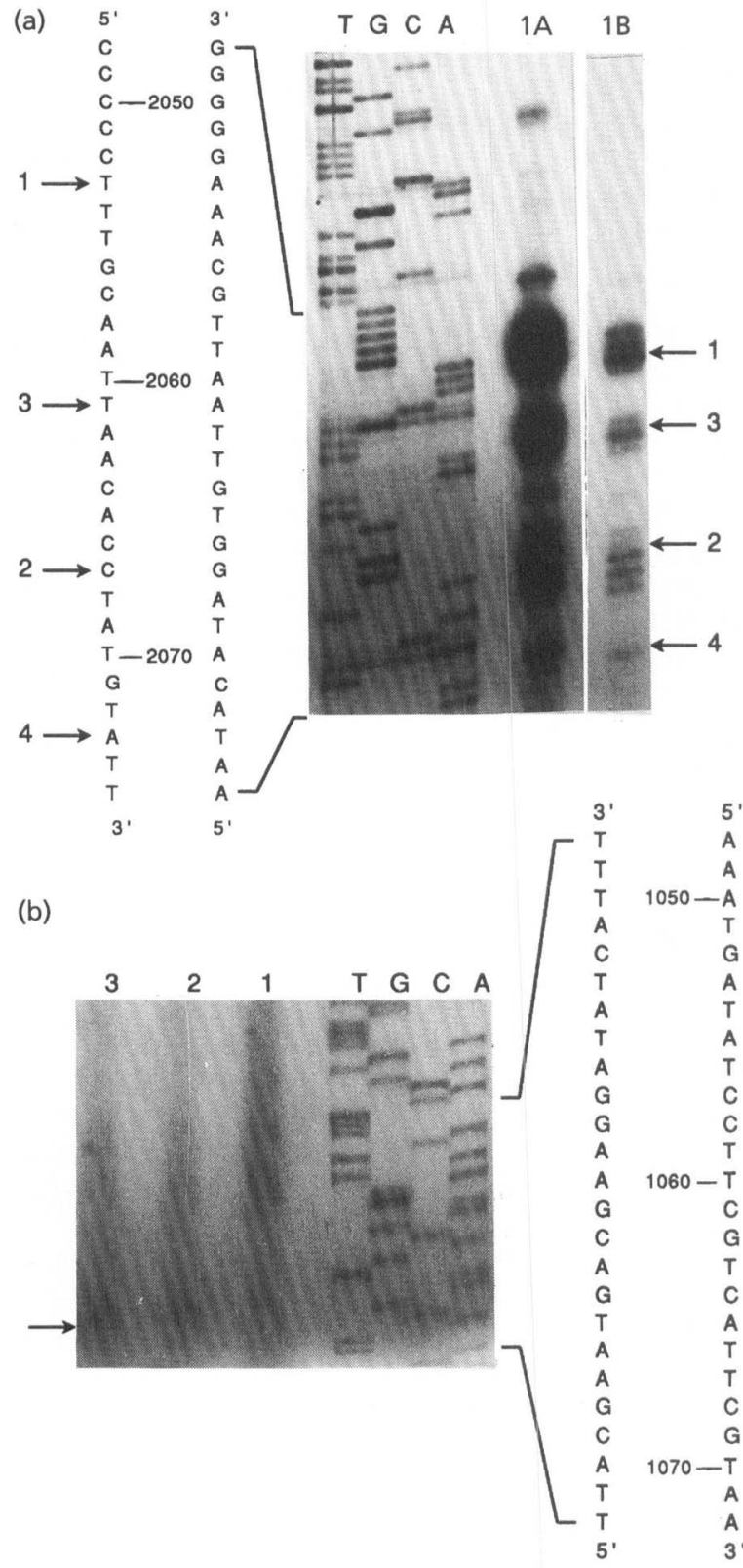

Fig. 4. Primer extension analysis of the $d s b A$ (a) and orfA (b) transcripts. Primers complementary to nucleotides 146-169 of $d s b A$ and to nucleotides $46-76$ of orfA were annealed to different amounts of total $E$. coli mRNA extracted from bacteria of strain CC118 harbouring plasmid pPB2196, and extended with moloney murine leukemia virus reverse transcriptase. The sequence ladders obtained using the same primers were run as size standards (lanes T, G, C and A). Arrows indicate initiation sites (see Results). (a) Total RNA $(0.5 \mu \mathrm{g})$ was used for $d s b A$ and lanes $1 \mathrm{~A}$ and $\mathrm{BB}$ correspond to $20 \mathrm{~h}$ and $3 \mathrm{~h}$ exposure time, respectively. (b) For orfA, $0.5 \mu \mathrm{g}$ (lane 1), $5 \mu \mathrm{g}$ (lane 2) and $25 \mu \mathrm{g}$ (lane 3) total RNA was used.

promoter. Consequently the HindIII-SspI fragment actually carries a promoter for $d s b A$, which very likely is located in the distal part of $\operatorname{orf} A$.

The origins of transcription of $d s b A$ and $\operatorname{orf} A$ were determined by primer extension analysis, using mRNA 

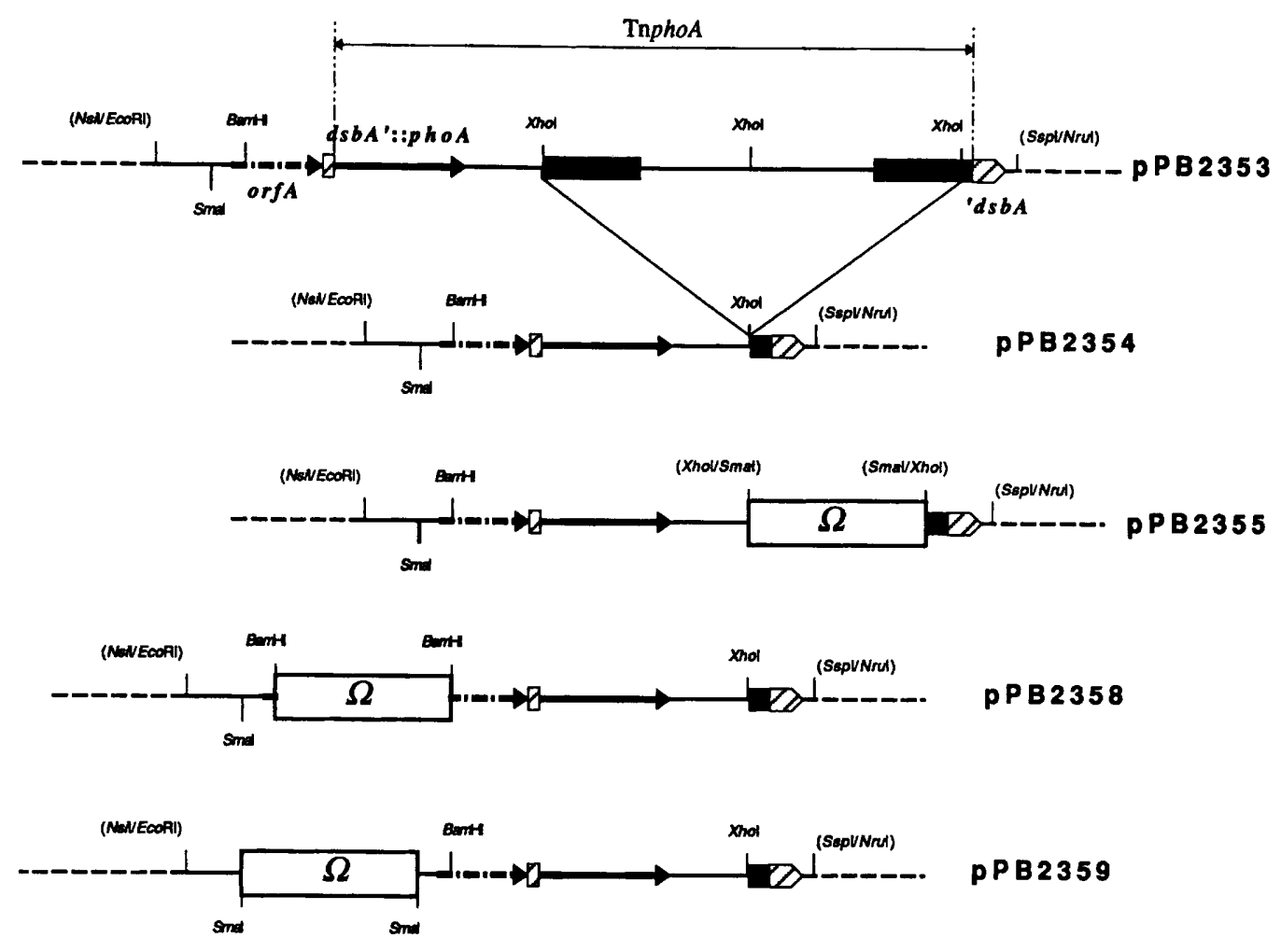

PPB2359

Fig. 5. Linear representation of the constructed plasmids carrying a $d s b A:: p h o A$ fusion. The thick hatched arrow indicates the $d s b A$ gene, and the thin solid arrow the 'phoA gene of TnphoA. The dash-dot arrow is the orfA gene. The thick solid bars are the is regions of the TnphoA transposon. The $\Omega$ fragment is indicated as a box. Thin dashed lines correspond to vector sequences. The restriction sites in parentheses are those which have been lost in the construction of the plasmids.

extracted from cells of strain CC118 harbouring pPB2196. mRNA $(0.5 \mu \mathrm{g})$ was first hybridized with a ${ }^{32} \mathrm{P}$-labelled 32 mer oligonucleotide complementary to nucleotide position 146-169 of the $d s b A$ gene (see Methods). The length of the cDNAs obtained after the action of reverse transcriptase corresponded to a main initiation point at the $T$ in position 2053 of our sequence (Fig. 4). The most probable -10 box (TACAAG) is located 8 nucleotides upstream from this point and shows $66 \%$ sequence identity with the $-10 \sigma^{70}$-dependent consensus box. The predicted -35 box (TTTATA) is 16 nucleotides upstream of the -10 box and also shows $66 \%$ identity with the $-35 \sigma^{70}$-dependent consensus sequence (Fig. 2 ). The most noteworthy feature of this promoter is its localization inside the terminal part of the $\operatorname{orf} A$ gene. Several closely linked initiation points of minor importance were also observed (Fig. 4), but they did not correspond to unequivocal promoter sequences.

The origin of transcription of $\operatorname{orf} A$ was determined with the same method using an oligonucleotide complementary to nucleotide position 46-76 of the $\operatorname{orf} A$ gene (see Methods). To obtain a weak signal, $25 \mu \mathrm{g}$ of RNA was necessary. The $\operatorname{orf} A$ origin of transcription was found at the $\mathrm{T}$ in position 1067,24 nucleotides upstream from the orf $A$ initiation codon. The sequence TATCCT located 8 nucleotides upstream from the origin of transcription is predicted to be the -10 box (Fig. 2). The -35 box is more difficult to identify, and the most likely sequence is TTGTAA located 29 nucleotides upstream from the -10 box, a distance which is not typical for a $\sigma^{70}$-dependent consensus promoter. One interesting feature of this promoter is the presence of the sequence TGn just before the -10 box. This upstream sequence, found in promoters having the major -10 consensus sequence, allows initiation without the help of the -35 region (Kumar et al., 1993). The characteristics of this promoter will be discussed below (see Discussion). Another interesting feature is the poor conservation of the Shine-Dalgarno (SD) sequence of $\operatorname{orf} A$, for which only three successive nucleotides (GGA) match the known consensus (Shine \& Dalgarno, 1974).

\section{Can dsbA be transcribed from the orfA promoter?}

The location of a $d s b A$-proximal promoter inside the orf $A$ gene, the characterization of an $\operatorname{orf} A$ promoter and the lack of transcription termination signals between $\operatorname{orf} A$ 


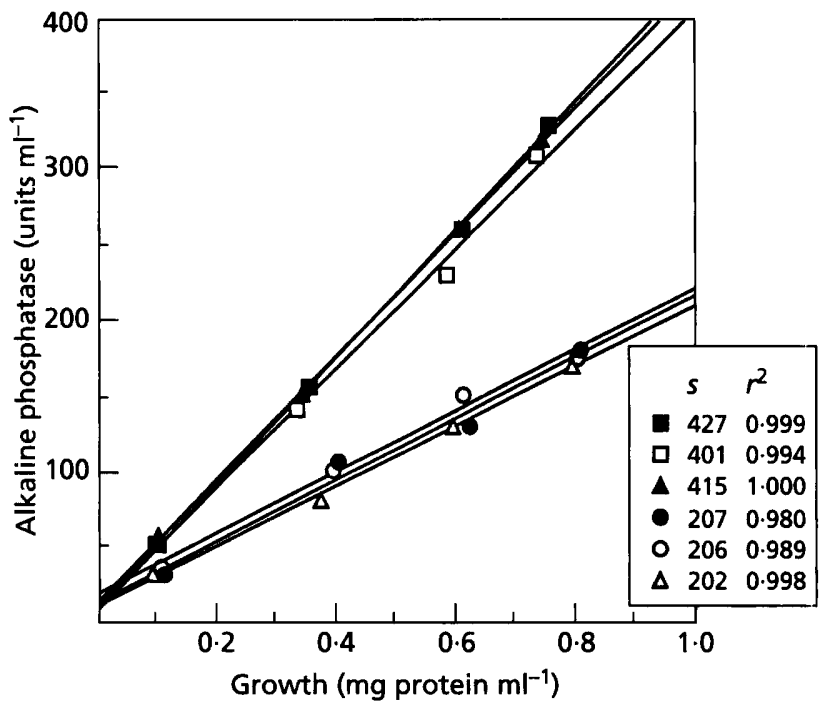

Fig. 6. Differential rate of alkaline phosphatase synthesis originating from plasmids carrying the $d s b A:: p h o A$ fusion. Bacteria of strain CC118 carrying plasmids pPB2354 ( $\square$ ), pPB2355 ( $\square$ ), pPB2358 (O), pPB2359 (A), pPB2360 (O) and pPB2394 $(\triangle)$ were grown in TYE medium at $37^{\circ} \mathrm{C}$ in the presence of Amp $\left(200 \mu \mathrm{g} \mathrm{ml}^{-1}\right)$ and alkaline phosphatase activity was measured as described in Methods. Each point represents the mean of five results made on independently collected samples. The SEM was calculated and found to be $<2 \%$ for each measure (not represented). In each case, the slope $(s)$ and the coefficient of correlation $\left(r^{2}\right)$ are indicated.

and $d \operatorname{sb} A$ raise the possibility of a dual promoter transcription of $d s b A$. If $d s b A$ and $\operatorname{orf} A$ belong, at least partly, to the same transcriptional unit, the contribution of each promoter to DsbA expression remains to be evaluated. This can be done by inserting a transcription and translation termination element between the two promoters and evaluating DsbA expression. A convenient way would be to measure the expression of alkaline phosphatase (AP) produced from a $d s b A:$ : Tnpho $A$ downstream fusion. One such fusion obtained by $\operatorname{Tn} p h o A$ insertion between nucleotides 79 and 80 of the $d s b A$ gene has already been described and is carried on plasmid pPB2317 (Belin et al., 1994). The resulting processed hybrid protein, which contains only seven amino acid residues of the amino-terminal part of DsbA, is stable in the periplasmic space. The $d s b A:: \operatorname{Tn} p b o A$ gene fusion was isolated from plasmid pPB2317 on a $7.7 \mathrm{~kb} \mathrm{HpaI}$ fragment and was inserted between the $H p a \mathrm{I}$ sites of plasmid pPB2352 (see Fig. 1), yielding plasmid pPB2353. This plasmid which carries the fusion, the whole $\operatorname{orf} A$ gene and part of the mob sequence was shortened by XboI deletion to remove the transposase activity and some redundant restriction sites, yielding pPB2354 (Fig. 5). The $\Omega$ interposon was inserted into pPB2354 at different positions: at the $X b o \mathrm{I}$ site downstream from the fusion (pPB2355), at the BamHI site located in the orf $A$ gene (pPB2358) and at the SmaI site lying upstream from the $\operatorname{orf} A$ promoter (pPB2359). Each of these plasmids was introduced into bacteria of strain CC118 (dsb $\left.A^{+} \Delta p b o A\right)$.
Transformants were grown on TYE at $37^{\circ} \mathrm{C}$ and AP activity was measured. Insertion of the $\Omega$ fragment outside of the $\operatorname{orf} A-d s b A$ region did not change AP activity relative to that observed with the original plasmid pPB2354. In contrast, interruption of transcription within the $\operatorname{orf} A$ gene in $\mathrm{pPB} 2358$ reduced AP activity by about $50 \%$ at all stages of growth (compare the slopes of the lines on Fig. 6).

Two deletions were made around the $\operatorname{orf} A$ promoter on plasmid pPB2354 and the activity of AP in cultures of strain CC118 containing each plasmid was measured. The first deletion extends from the $S m a \mathrm{I}$ site to the EcoRV site (plasmid pPB2360) and the second from the EcoRV site to the $B a m \mathrm{HI}$ site located within the orf $A$ gene (plasmid pPB2394). In each case, the deletion promoted about a twofold reduction of expression of AP (Fig. 6), as previously observed with plasmid pPB2358. This result shows that the $d s b A$ gene is actually transcribed from the $\operatorname{orf} A$ promoter, and confirms the position of the -10 box in this promoter around the EcoRV site, a result in good agreement with the primer extension experiment described above.

\section{Consequences of orfA disruption}

The $\operatorname{orf} A$ gene carried by plasmid pPB2216 was inactivated by insertion of the $\Omega$ fragment into the unique BamHI site (pPB2217, see Fig. 1). The orf $A:: \Omega$ construct was introduced into the chromosome by homologous recombination (Gay, 1984). Transformants of SBS2171 $\left(\right.$ pol $\left.A_{\mathrm{ts}}\right)$ carrying plasmid pPB2217 were selected by growth in the presence of Str and Spc (50 $\mu \mathrm{g} \mathrm{ml}^{-1}$ each). The plasmid was forced to integrate into the chromosome at $42^{\circ} \mathrm{C}$ in serial cultures containing low levels of Str and Spc $\left(10 \mu \mathrm{g} \mathrm{ml}^{-1}\right.$ each). Its return to the autonomous state by further growth at $30^{\circ} \mathrm{C}$ in the presence of $200 \mu \mathrm{g}$ Amp $\mathrm{ml}^{-1}$ was followed by plating in the presence of Amp $\left(200 \mu \mathrm{g} \mathrm{ml}^{-1}\right)$, and Str and Spc $\left(50 \mu \mathrm{g} \mathrm{ml}^{-1}\right.$ each) to discriminate between clones carrying the original plasmid with $\Omega$ in the multicopy state (large colonies) and the recombinant clones carrying only a chromosomal copy of $\boldsymbol{\Omega}$ (small colonies). Bacteria from a small colony were grown at $42{ }^{\circ} \mathrm{C}$ without antibiotic to eliminate the recombinant plasmid. A stock of phage $\mathrm{P} 1$ made on such a recombinant was used to transduce bacteria of strain K10 to $\operatorname{Str}^{\mathrm{r}} \mathrm{Spc}^{\mathrm{r}}$ (10 $\mu \mathrm{g} \mathrm{ml}{ }^{-1}$ each). A $\mathrm{Tet}^{\mathrm{r}} \mathrm{Str}^{\mathrm{r}} \mathrm{Spc}^{\mathrm{r}}$ and pol $A^{+}$transductant (SBS2227) was selected. Further transduction experiments made with this strain as donor showed that the $\operatorname{Str}^{\mathrm{r}} \mathrm{Spc}^{\mathrm{r}}$ character was integrated very close to $d s b A$.

To test further for the presence of $\Omega$ in the $\operatorname{orf} A$ gene of SBS2227, this region of the chromosome from bacteria of strain K10 and SBS2227 was amplified by PCR, using oligonucleotides complementary to sequences lying on each side of the BamHI site in which $\Omega$ was inserted (see Methods). The PCR products found for both strains showed the expected sizes, i.e. a single band of about $0.5 \mathrm{~kb}$ for $\mathrm{K} 10$ and a single band of about $2.5 \mathrm{~kb}$ for SBS2227. The $2.5 \mathrm{~kb}$ PCR band obtained from SBS2227 yielded a $2 \mathrm{~kb}$ band when digested with Bam HI (data not 
(a)

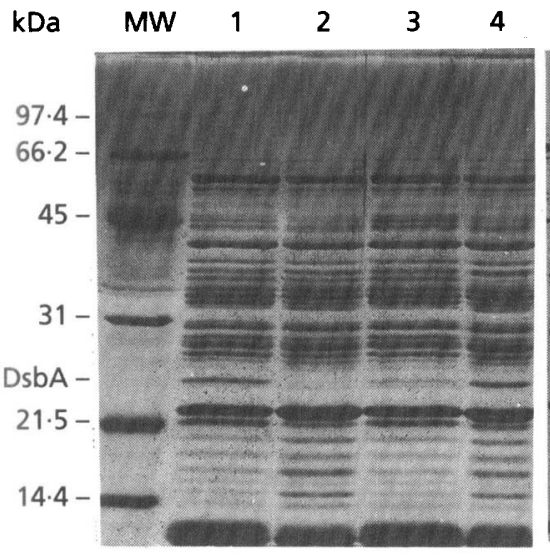

(b)

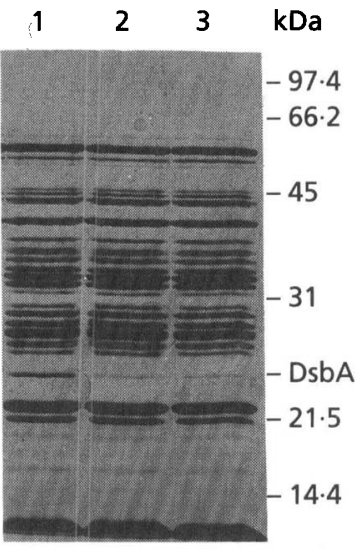

Fig. 7. Effect of the insertion of the $\Omega$ interposon in the orfA chromosomal gene on the production of the periplasmic DsbA. (a) Silver-stained SDS-polyacrylamide gel ( $13 \%$ acrylamide) run with shock fluids from bacteria of strains K10 (wild-type, lane 1), SBS2096 as control [dsbA71 (Oc), lane 2], SBS2227 (orfA:: $\Omega$ dsbA ${ }^{+}$, lane 3 ) and SBS2280 (dsbB::Tn10, lane 4) as control. (b) Similar staining of runs with shock fluids of K10(pHSG575) as control (lane 1), SBS2227(pHSG575) as control (lane 2) and SBS2227(pPB2144) (lane 3). pHSG575 is only the vector and PPB2144 carries the orf $A^{+}$ gene and a truncated $d s b A^{\prime}$ fragment encoding an inactive polypeptide (Belin et al., 1994). shown). This fragment, when religated into the Bam $\mathrm{HI}$ site of pBR322, conferred resistance to Str and Spc. This eliminates the possibility that an intact $\operatorname{orf} A$ gene would lie in tandem close to $\operatorname{orf} A:: \Omega$. Interrupting $\operatorname{orf} A$ by $\Omega$ on the chromosome of SBS2227 caused a drastic reduction in the amount of DsbA produced (Fig. 7a).

The ability of bacteria from strain SBS2227 to form disulfide bridges in DsbA-dependent periplasmic phosphatases was examined. The activities of $\mathrm{pH} 2.5$ acid phosphatase (AppA), glucose-1-phosphatase (Agp) and alkaline phosphatase (PhoA) were the same in SBS2227 and K10 (data not shown). Moreover, when bacteria of both strains were transformed with plasmids overproducing the same phosphatases, namely $\mathrm{pPB} 1132$ for AppA (Boquet $e$ t al., 1987), pEP1376 for Agp (Pradel \& Boquet, 1988) and pLIP5.0 for PhoA ( $p h o A$ under the control of the $\mathrm{P}_{t a c}$ promoter in the $\mathrm{pACYC177}$ vector; L. Cattolico, this laboratory, unpublished), none of these activities were reduced in SBS2227 (data not shown). Consequently, under the conditions used, disulfide bond formation was not altered by the presence of $\Omega$ in $\operatorname{orf} A$, showing that the $\operatorname{orf} A$ gene product itself is very likely not involved in this process.

To discover whether normal expression of $d s b A$ would require an intact $\operatorname{orf} A$ gene product, two sets of experiments were performed. Firstly, bacteria of strain SBS2227 were transformed with plasmid pPB2144 which carries the entire $\operatorname{orf} A$ gene cloned into the vector pHSG575. The amount of DsbA in the periplasmic space of the transformants was similar to that in SBS2227 (Fig. 7b). Secondly, the $\operatorname{orf} A$ gene carried by plasmid pPB2354 $(\operatorname{orf} A d s b A:: \operatorname{Tn} p h o A$ ) was mutated only by frameshifting to try to avoid a block of its transcription from the P2 promoter. The plasmid was cut with BamHI and the gaps were filled with T4 DNA polymerase before ligating, yielding plasmid pPB2395 (orf $\left.A^{-} d s b A:: \operatorname{Tn} p h o A\right)$. Nucleotide sequence analysis indicated that the $\operatorname{orf} A$ reading frame was actually destroyed (data not shown). Bacteria of strain SBS2227 were transformed with either pPB2354 or pPB2395 and the AP activity of the plasmidborne $d s b A:: \operatorname{Tn} p h o A$ fusion was measured in each case. Surprisingly, it was reduced by $30 \%$ by the frameshift mutation in $\mathrm{PPB} 2395$. However, when the second com-

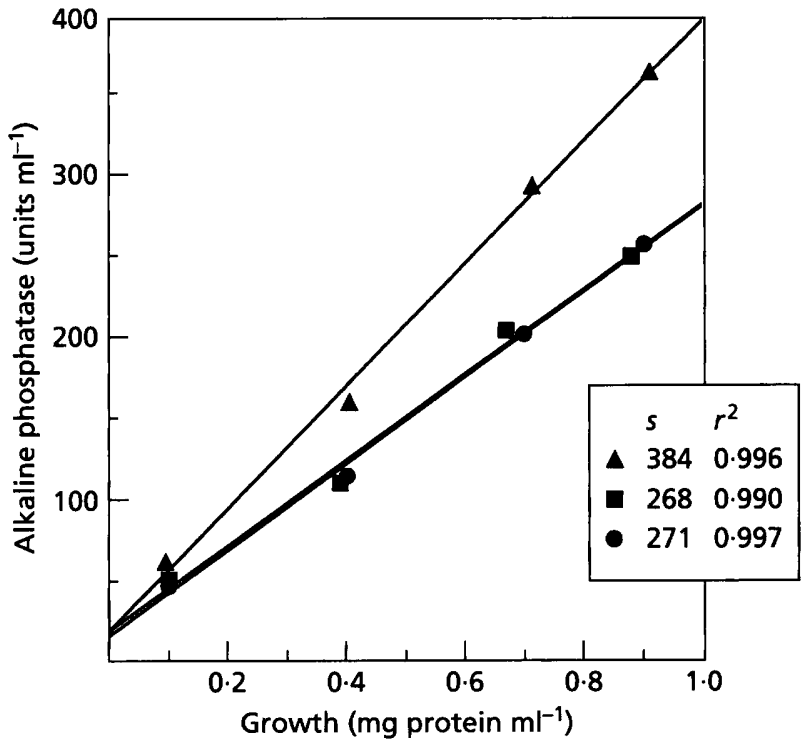

Fig. 8. Expression of alkaline phosphatase originating from the plasmid-borne $d s b A:: p h o A$ fusion in a strain carrying an orfA:: $\Omega$ insertion. Bacteria of strain SBS2227 carrying plasmids pPB2354 (A), pPB2395 ( $)$, and pPB2395 and pPB2144 (O) were grown in TYE medium at $37^{\circ} \mathrm{C}$ with Amp $\left(200 \mu \mathrm{g} \mathrm{ml}^{-1}\right)$ and alkaline phosphatase activity was measured and expressed as in Fig. 6.

patible plasmid pPB2144 (orf $A^{+}$) was introduced into SBS2227(pPB2395), the presence of orf $A^{+}$in trans did not restore the original AP activity (Fig. 8). Consequently, the frameshift mutation very likely interferes with transcription and the $\operatorname{orf} A$ gene product itself is not necessary for $d s b A$ expression.

\section{DISCUSSION}

The availability of MudII clones carrying the DNA region around $d s b A$ led us to investigate in greater detail the characteristics of $d s b A$ transcription. The analysis of the nucleotide sequence of the $d s b A$ region reported here confirms, with some modifications, that the region lying upstream from $d s b A$ corresponds to an open reading 
frame, $\operatorname{orf} A$, reported as 0328 by Plunkett $e t$ al. (1993). However, we have described a transcriptional organization of the $d s b A$ gene which is different from that proposed by Plunkett and coworkers. Our findings indicate that $d s b A$ can be transcribed from an internal promoter located in the distal portion of orf $A$ (o328). This promoter, $\mathrm{P} 1$, shows $66 \%$ sequence identity with the $\sigma^{70}$-dependent promoter consensus sequence. It can also be transcribed from another promoter, P2, located upstream from $\operatorname{orf} A$. The $\mathrm{P} 2$ promoter, whose -10 box (TATccT) has $66 \%$ identity with the $\sigma^{70}$-dependent -10 box consensus sequence, does not show any typical and correctly spaced -35 box. However, measures of alkaline phosphatase activity in cultures of strains harbouring a plasmid with a $d s b A:: \operatorname{Tn} p h o A$ fusion under the control of only one promoter (P1) or both promoters (P1 and P2) indicated that each promoter participates approximately equally to the transcription of the $d s b A:: \operatorname{Tn} p b o A$ gene fusion. This means that the initiation of transcription at the -35 boxless promoter P2 is as efficient as that originating from the complete $\sigma^{70}$-dependent promoter $\mathrm{P} 1$. One noteworthy feature of the P2 promoter is the presence of an additional TGn motif just before its -10 box. It is known that such a motif can be sufficient to allow a strong initiation in vitro and in vivo from promoters lacking the -35 box but showing a 'major' -10 sequence. However non-major -10 boxes with imperfect. nucleotides in the fourth and/or fifth position of the typical $\sigma^{70}$ consensus sequence (TATaaT) can also be functional (Kumar et al., 1993; Belyaeva et al., 1993). Raibaud \& Schwartz (1984) also reported that positively controlled promoters generally contain little sequence similarity in the -35 region. However, the comparison of several reported consensus sequences corresponding to the binding sites of various transcription regulators (cAMP-CRP, Ebright, 1982; OmpR, Igarashi et al., 1991; TyrR, Yang et al., 1991; Lrp, Wang \& Calvo, 1993; IHF, Goodrich et al., 1990) with the DNA sequence upstream from $\operatorname{orf} A \operatorname{did}$ not show significant similarity. Studies on the regulation of the $d s b A$ gene using chromosomal $d s b A:: \operatorname{Tn} l a c Z$ fusion are now under investigation.

We have shown that $\operatorname{orf} A$ is actually a gene whose product has been identified as a $39 \mathrm{kDa}$ protein, probably localized to the cytoplasm. The level of expression of this protein, which is independent of the $\operatorname{orf} A$ upstream region cloned, remained very low though the $\operatorname{orf} A \mathrm{P} 2$ promoter was as active as the $d s b A \mathrm{P} 1$ promoter. Even when the $\operatorname{orf} A$ gene was placed under the control of the induced $\mathrm{P}_{t a c}$ promoter, the production of the $39 \mathrm{kDa}$ $\operatorname{orf} A$ gene product was not elevated (P. Belin \& P. L. Boquet, unpublished result). This result suggests that the low expression of $\operatorname{orf} A$ does not result from a weak promoter activity but rather from a post-transcriptional event. Its very poor SD sequence is probably the cause of this low yield of protein synthesis.

The role of $\operatorname{orf} A$ was investigated by destruction of the chromosomal copy of $\operatorname{orf} A$ with an $\Omega$ fragment. This knock-out had no effect on growth and cell viability. The formation of disulfide bonds in the periplasmic space was not affected, even when substrate proteins were over- produced. The $\operatorname{orf} A$ gene product is thus not required for disulfide bond formation. Curiously, when the translation of $\operatorname{orf} A$ was aborted by introducing a frameshift mutation in the gene, the expression of a downstream $d s b A:: \operatorname{Tn} p h o A$ fusion was reduced by about one-third. However, the presence in trans of several copies of the wild-type $\operatorname{orf} A$ gene did not restore the wild-type AP activity of the fusion. This result could be explained by a phenomenon of transcriptional polarity (Adhya \& Gottesman, 1978) in which the absence of orf $A$ translation could lead to the premature release of RNA polymerase from $\operatorname{orf} A$. The physiological role of the $\operatorname{orf} A$ gene product remains to be elucidated.

Dsb-mediated disulfide bond formation appeared to be very efficient and allowed the overproduction of several cystine-containing prokaryotic and eukaryotic proteins in the periplasmic space (AppA, Agp and PhoA, Belin et al., 1994; urokinase-type plasminogen activator and tissuetype plasminogen activator, Bardwell et al., 1993). We have shown that reducing the amount of DsbA in the periplasmic space by limiting its transcription at promoter P1 on the single chromosomal gene does not change the efficiency of disulfide bond formation in the overproduced AppA, Agp and PhoA proteins. Thus, in a wild-type strain, DsbA is in excess for normal cell functions. The reduced state of DsbA is more stable than the oxidized one (Zapun et al., 1993; Wunderlich et al., 1993). One limiting factor of disulfide bond formation could be the kinetics of reoxidation of the DsbA protein after its contact with the membrane-bound DsbB protein and not the probability of DsbA-DsbB contact formation. Since in a wild-type strain more than half the DsbA is found in a reduced state in vivo (Bardwell et al., 1993), it is possible that reducing the total amount of DsbA by about the same factor mostly affects the pool of the reduced form with little change in that of the oxidized one. Experiments aimed to reduce the DsbA pool down to a critical threshold are now in progress.

We thank Dr C. Iobi for communication of sequence information prior to publication. We thank Dr E. Dassa for helpful discussion. We are indebted to Dr D. Kotlarz for her advice concerning mRNA preparations and primer extension analysis. We are grateful to L. Cattolico for the gift of the pLIP5.0 plasmid. We also thank Dr C. Mann for critically reading the manuscript.

Adhya, S. \& Gottesman, M. (1978). Control of transcription termination. Annu Rev Biochem 47, 967-996.

Aiba, H., Adhya, S. \& de Crombrugghe, B. (1981). Evidence for two functional gal promoters in intact Escherichia coli cells. $J$ Biol Chem 256, 11905-11910.

Akiyama, Y., Kamitani, S., Kusukawa, N. \& Ito, K. (1992). In vitro catalysis of oxidative folding of disulfide-bonded proteins by the Escherichia coli $d s b A(p p f A)$ gene product. $J$ Biol Chem 267, 22440-22445.

Bardwell, J. C. A., McGovern, K. \& Beckwith, J. (1991). 
Identification of a protein required for disulfide bond formation in vivo. Cell 67, 581-589.

Bardwell, J. C. A., Lee, J. O., Jander, G., Martin, N., Belin, D. \& Beckwith, J. (1993). A pathway for disulfide bond formation in vivo. Proc Natl Acad Sci US A 90, 1038-1042.

Barth, P. T., Bust, C., Hawkins, H. C. \& Freedman, R. B. (1988). Protein disulphide-isomerase activity in bacterial osmotic shock preparations. Biochem Soc Trans 16, 57.

Belin, P. \& Boquet, P. L. (1993). A second gene involved in the formation of disulfide bonds in proteins of the Escherichia coli periplasmic space. C R Acad Sci Paris 316, 469-473.

Belin P., Quéméneur, E. \& Boquet, P. L. (1994). A pleiotropic acid phosphatase-deficient mutant of Escherichia coli shows premature termination in the $d s b A$ gene. Use of $d s b A:: p b o A$ fusions to localize a structurally important domain in DsbA. Mol \& Gen Genet 242, 23-32.

Belyaeva, T., Griffiths, L., Minchin, S., Cole, J. \& Busby, S. (1993). The Escherichia coli cys $G$ promoter belongs to the 'extended -10 ' class of bacterial promoters. Biochem J 296, 851-857.

Blum, H., Beier, H. \& Gross, H. J. (1987). Improved silver staining of plant proteins, RNA and DNA in polyacrylamide gels. Electrophoresis 8, 93-99.

Boquet, P. L., Manoil, C. \& Beckwith, J. (1987). Use of 'Tnpho $A$ to detect genes for exported proteins in Escherichia coli: identification of the plasmid-encoded gene for a periplasmic acid phosphatase. $J$ Bacteriol 169, 1663-1669.

Dailey, F. E. \& Berg, H.C. (1993). Mutants in disulfide bond formation that disrupt flagellar assembly in Escherichia coli. Proc Natl Acad Sci US A 90, 1043-1047.

Dassa, E., Cahu, M., Desjoyaux-Cherel, B. \& Boquet, P. L. (1982). The acid phosphatase with optimum $\mathrm{pH}$ of 2.5 of Escherichia coli: physiological and biochemical study. J Biol Chem 257, 6669-6676.

Dessen, P., Fondrat, C., Valencien, C. \& Mugnier, C. (1990). BISANCE: a French service for access to biomolecular sequence databases. Cabios 6, 355-356.

Ebright, R. H. (1982). Sequence homologies in the DNA of six sites known to bind to the catabolite activator protein of Escherichia coli. In Molecular Structure and Biological Activity, pp. 91-99. Edited by J. P. Griffin \& W. L. Duax. New York: Elsevier.

Gay, N. J. (1984). Construction and characterization of an Escherichia coli strain with a uncI mutation. $J$ Bacteriol 158, 820-825.

Gething, M. J. \& Sambrook, J. (1992). Protein folding in the cell. Nature 355, 33-45.

Goodrich, J. A., Schwartz, M. L. \& McClure, W. R. (1990). Searching for and predicting the activity of sites for DNA binding proteins: compilation and analysis of the binding sites for Escherichia coli integration host factor. Nucleic Acids Res 18, 4993-5000.

Igarashi, K., Hanamura, A., Makino, K., Aiba, H., Aiba, H., Mizuno, T., Nakata, A. \& Ishihama, A. (1991). Functional map of the a subunit of Escherichia coli RNA polymerase: two modes of transcription activation by positive factors. Proc Natl Acad $S_{c i}$ US A 88, 8958-8962.

Kamitani, S., Akiyama, Y. \& Ito, K. (1992). Identification and characterization of an Escherichia coli gene required for the formation of correctly folded alkaline phosphatase, a periplasmic enzyme. $E M B O$ J 11, 57-62.

Khalil, I., Lepage, V. \& Hors, J. (1992). Typage HLA de classe II par amplification d'ADN et hybridation avec des oligonucléotides spécifiques. In Amplification Enqymatique de Séquences Nucléotidiques par PCR, pp. 31-38. Edited by O. Acuto \& M. Tosi. Paris: Editions INSERM.
Kohara, Y., Akiyama, Y. \& Isono, K. (1987). The physical map of the whole $E$. coli chromosome. Application of a new strategy for rapid analysis and sorting of a large genomic library. Cell 50, 495-508.

Kumar, A., Malloch, R. A., Fujita, N., Smillie, D. A., Ishihama, A. \& Hayward, R. S. (1993). The minus 35-recognition region of Escherichia coli sigma 70 is inessential for initiation of transcription at an 'extended minus 10' promoter. J Mol Biol 232, 406-418.

Laemmli, U. K. (1970). Cleavage of structural proteins during the assembly of the head of bacteriophage T4. Nature 227, 680-685.

Marck, C. (1988). 'DNA Strider': a ' $C$ ' program for the fast analysis of DNA and protein sequences on the Apple MacIntosh family of computers. Nucleic Acids Res 16, 1829-1836.

Miller, J. H. (1972). Experiments in Molecular Genetics. Cold Spring Harbor, NY: Cold Spring Harbor Laboratory.

Missiakas, D., Georgopoulos, C. \& Raina, S. (1993). Identification and characterization of the Eschericbia coli gene $d s b B$, whose product is involved in the formation of disulfide bonds in vivo. Proc Natl Acad Sci US A 90, 7084-7088.

Neu, H. C. \& Heppel, L. A. (1965). The release of enzymes from Escherichia coli by osmotic shock and during the formation of spheroplasts. J Biol Chem 240, 3685-3692.

Peek, J. A. \& Taylor, R. K. (1992). Characterization of a periplasmic thiol:disulfide interchange protein required for the functional maturation of secreted virulence factors of Vibrio cholerae. Proc Natl Acad Sci US A 89, 6210-6214.

Plunkett, G., Burland, V., Daniels, D. L. \& Blattner, F. R. (1993). Analysis of the Escherichia coli genome. III. DNA sequence of the region from $87 \cdot 2$ to $89 \cdot 2$ minutes. Nucleic Acids Res 21, 3391-3398.

Pradel, E. \& Boquet, P. L. (1988). Acid phosphatases of Escherichia coli: molecular cloning and analysis of agp, the structural gene for a periplasmic acid glucose-1-phosphatase. J Bacteriol 170, 4916-4923.

Prentki, P. \& Krisch, H. M. (1984). In vitro insertional mutagenesis with a selectable DNA fragment. Gene 29, 303-313.

Raibaud, O. \& Schwartz, M. (1984). Positive control of transcription initiation in bacteria. Annu Rev Genet 18, 173-206.

Sambrook, J., Fritsch, E. F. \& Maniatis, T. (1989). Molecular Cloning: a Laboratory Manual, 2nd edn. Cold Spring Harbor, NY: Cold Spring Harbor Laboratory.

Sancar, A., Haok, A. M. \& Rupp, W. D. (1979). Simple method for identification of plasmid-coded proteins. J Bacteriol 137, 692-693.

Sharp, P. M. \& Li, W.-H. (1987). The codon adaptation index - a measure of directional synonymous codon usage bias, and its potential applications. Nucleic Acids Res 15, 1281-1295.

Shine, J. \& Dalgarno, L. (1974). The $3^{\prime}$-terminal sequence of Escherichia coli $16 \mathrm{~S}$ ribosomal RNA: complementarity to nonsense triplets and ribosome binding sites. Proc Natl Acad Sci USA 71, 1342-1346.

Silhavy, T. J., Berman, M. L. \& Enquist, L. W. (1984). Experiments With Gene Fusions. Cold Spring Harbor, NY: Cold Spring Harbor Laboratory.

Takeshita, S., Sato, M., Masahashi, W. \& Hashimoto-Gotoh, T. (1987). High-copy-number and low-copy-number plasmid vectors for lac $Z$ complementation and chloramphenicol or kanamycinresistance selection. Gene 61, 63-74.

Tomb, J. F. (1992). A periplasmic protein disulfide oxidoreductase is required for transformation of Haemophilus influenzae Rd. Proc Natl Acad Sci USA 89, 10252-10256.

Wang, Q. \& Calvo, J. M. (1993). Lrp, a global regulatory protein of Escherichia coli, binds co-operatively to multiple sites and activates transcription of ilvIH. J Mol Biol 229, 306-318. 
Wunderlich, M., Jaenicke, R. \& Glockshuber, R. (1993). The redox properties of protein disulfide isomerase (DsbA) of Eschericbia coli result from a tense conformation of its oxidized form. $J \mathrm{Mol}$ Biol 233, 559-566.

Yang, J., Ganesan, S., Sarsero, J. \& Pittard, A. J. (1993). A genetic analysis of various functions of the TyrR protein of Escherichia coli. J Bacteriol 175, 1767-1776.

Yu, J., Webb, H. \& Hirst, T. R. (1992). A homologue of the Escherichia coli DsbA protein involved in disulphide bond formation is required for enterotoxin biogenesis in Vibrio cholerae. Mol Microbiol 6, 1949-1958.

Zapun, A., Bardwell, J. C. A. \& Creighton, T. E. (1993). The reactive and destabilizing disulfide bond of DsbA, a protein required for protein disulfide bond formation in vivo. Biochemistry 32, 5083-5092.

Received 18 May 1994; revised 25 July 1994; accepted 11 August 1994. 